Helgoländer wiss. Meeresunters. 24, 256-263 (1973)

\title{
In situ quantitative sampling of benthic organisms
}

\author{
B. F. KEEGAN \& G. KÖNNECKER \\ Zoology Department, University College; Galway, Ireland
}

KURZFASSUNG: Quantitatives Sammeln von Bodenorganismen in situ. Die Tiefe, bis zu der sich eine Reihe von Vertretern der Endofauna eingraben und die Möglichkeiten, diese mit entsprechenden Fanggeräten zu erbeuten, werden kurz erörtert. Für ein möglichst quantitatives Aufsammeln sollte das Fanggerät die Fauna bis zu einer Tiefe von $50 \mathrm{~cm}$ erfassen. Ein Fanggerät nach dem Prinzip der Saugpumpe, das von Tauchern gehandhabt werden kann, wird beschrieben und diskutiert. Dieser "Air-lift" wurde sehr erfolgreich bei einer Vielzahl von Bodentypen für Faunenuntersuchungen angewendet. Ferner werden die Konstruktion und Anwendung einer neuen Lotröhre, die nahezu ungestörte Proben für biologische Zwecke liefert, diskutiert.

\section{INTRODUCTION}

Contemporary studies in marine benthic ecology show a certain preoccupation with problems mathematical. In most instances these studies make but token concession to the reality that available data may be wholly unreliable. This unreliability of data points to the continued and continuing use of inadequate sampling techniques.

Whilst various authors (Holme 1964, Hopkins 1964, Menzies \& Rowe 1968) list criteria for the ideal soft-bottom quantitative benthos sampler, the adoption of one system or another by the benthic ecologist would seem more often to result from a subjective and superficial appeal than from any real appreciation of the sampler's worth. This is manifest in a frustrating disparity of approach and sampling technique which renders strict comparison of quantitative results, from different geographical areas, almost impossible.

Having embarked upon a programme of benthic studies some years ago, the writers were content to operate along lines uncritically in keeping with their inexperience of benthic sampling methodology. However, the facility of being able to observe the 'in situ' functioning of various grabs and dredges soon redirected the project's emphasis. What began as a 'conventional' - and consequently incomplete reporting of macrofaunal distribution both on and within the sea bed became instead a quest for an efficient and reliable quantitative bottom sampler. This quest was but partially satisfied by existing sampling technology.

A very limiting feature of many grabs and dredges is their inability to dig deeply into the substrate. Most samplers rarely penetrate beyond a depth of $10 \mathrm{~cm}$.* This may

The KNUDSEN bottom-corer (KNUDSEN 1927) and the REINECK box-sampler (REINECK 1958) are both capable of 'deep penetration' sampling. However, these instruments are heavy and awkward and can only be operated from large vessels. 
be considered adequate by those who hold the view that ". . the majority of benthic animals may be found in the top $10 \mathrm{~cm}$ of sediment" (see Holme 1964). It has been the writers' experience, however, that an important fraction of the standing crop can and does occur much deeper within the deposit. In fact, where maerl substrates are concerned, as much as $98 \%$ of the standing crop may be found in the $20-40 \mathrm{~cm}$ zone!

Some workers contend that animals which lie outside the range of the "normal grab" are similarly unavailable to benthic predators and are, consequently, only of marginal importance. This view has been sufficiently contested by MAsse (1970) to forego further comment here.

Findings such as summarized in Table 1 clearly show that for a benthos sampler to capture the available macrofauna it must penetrate the deposit to a depth of, at least, $50 \mathrm{~cm}$. Recent advances with diver-operated "suction samplers" indicated that these devices were capable of taking samples as deep and as accurate as could be obtained by any means. After many sea trials, the writers adopted one such instrument for quantitative work. In addition, a very useful core sampler, operating on the same 'air-lift' principle, was devised and constructed.

Table 1

Depth ranging (within the substrate) of some macrobenthic animals

\begin{tabular}{|c|c|c|}
\hline Species & $\begin{array}{l}\text { Maximum depth } \\
( \pm 2 \mathrm{~cm})\end{array}$ & Substrate type \\
\hline $\begin{array}{l}\text { Pacbycerianthus multiplicatus } \\
\text { Peachia bastata } \\
\text { Virgularia mirabilis }\end{array}$ & $\begin{array}{l}90 \\
25 \\
40\end{array}$ & $\begin{array}{l}\text { mud } \\
\text { coarse sand and gravel } \\
\text { mud }\end{array}$ \\
\hline $\begin{array}{l}\text { Golfingia elongatum } \\
\text { Golfingia vulgare } \\
\text { Sipunculus nudus }\end{array}$ & $\begin{array}{l}40 \\
36 \\
60\end{array}$ & $\begin{array}{l}\text { clay } \\
\text { clay } \\
\text { maerl debris }\end{array}$ \\
\hline $\begin{array}{l}\text { Marpbysa sanguinea } \\
\text { Glycera convoluta } \\
\text { Glycera alba } \\
\text { Glycera gigantea } \\
\text { Melinna palmata }\end{array}$ & $\begin{array}{l}48 \\
26 \\
38 \\
50 \\
22\end{array}$ & $\begin{array}{l}\text { shelly mud } \\
\text { maerl and mud } \\
\text { maerl debris } \\
\text { shell gravel } \\
\text { sandy mud }\end{array}$ \\
\hline Upogebia spp. & 46 & clay \\
\hline Balcis alba & 40 & maerl debris \\
\hline $\begin{array}{l}\text { Dosinia exoleta } \\
\text { Dosinia lupinus } \\
\text { Lutraria elliptica } \\
\text { Lutraria angustior } \\
\text { Venus fasciata } \\
\text { Astarte triangularis } \\
\text { Thracia pubescens } \\
\text { Mya arenaria } \\
\text { Solen ensis } \\
\text { Solen siliqua }\end{array}$ & $\begin{array}{l}40 \\
19 \\
61 \\
45 \\
28 \\
26 \\
30 \\
50 \\
54 \\
62\end{array}$ & $\begin{array}{l}\text { shell gravel and maerl debris } \\
\text { shell gravel and maerl debris } \\
\text { sand } \\
\text { maerl debris } \\
\text { maerl debris } \\
\text { maerl debris } \\
\text { shelly mud } \\
\text { clay } \\
\text { sand } \\
\text { sand }\end{array}$ \\
\hline $\begin{array}{l}\text { Leptosynapta inhaerens } \\
\text { Psendocucumis mixta } \\
\text { Paracentrotus lividus } \\
\text { Echinocardium chordatum }\end{array}$ & $\begin{array}{l}48 \\
38 \\
36 \\
25\end{array}$ & $\begin{array}{l}\text { fine maerl debris } \\
\text { maerl debris } \\
\text { loose maerl } \\
\text { sand }\end{array}$ \\
\hline
\end{tabular}


The basic functioning of both systems posed few difficulties; it was the operational logistics which proved most troublesome. In regard to these latter problems, published work proved singularly unhelpful. Technical papers on sampling methodology tend to focus on physical description and constructional detail whilst scant attention is given to the possible operational difficulties.

\title{
METHODS AND TECHNIQUES
}

\author{
Suction sampler
}

The sampler employed (Fig. 1) was basically that described by BARNETT \& HARDY (1967).* Modifications to the original design included the following: (a) the provision of a 'self-contained' air supply, thus making the unit independent of the support vessel; (b) a lessening of the distance between the air inlet and the lower pipe opening (this rendered the sampler more efficient and markedly reduced its air consumption); (c) the development of a 'fool-proof' system of sample bag attachment and removal (this was very necessary when working in conditions of poor visibility); (d) an overall streamlining of the lower pipe section (this entailed removal of air-flow control from the pipe itself to the air bottle. Such streamlining was called for when trying to sample deep within a 'cylinder of reference' - see below).

Use of a suction sampler for quantitative work requires that the operator be able to discretely 'confine' a known volume of sea bottom. BRETT (1964) overcame this problem by hand-pushing a steel frame some $15 \mathrm{~cm}$ into the substrate. However, as experienced by BARNETT \& HARDY (1967), compact sediments will resist the feeble penetrating capacity of such a frame. These workers accordingly used another application of the air-lift principle (see MACKERETH 1958) to drive a sampling cylinder some $60 \mathrm{~cm}$ into the deposit. The writers found this method cumbersome, time consuming and quite useless in coarse sediments. A 'cylinder of reference' such as described by Masse (1970) proved just as effective and easier to operate.

Fashioned from stainless steel, the cylinder had an uneven bevelled cutting edge as its lower rim. The upper rim was provided with two pairs of vertical projections which, in turn, supported a circular hand grip. By applying semi-rotatory (alternating push/pull) movement to the cylinder, two divers could readily force it the required distance into the most compact sand. For shell-gravel and maerl deposits, accessory cutting edges proved most helpful.

Full use of the air-lift requires that two divers be in attendance at all times. A random positioning of the cylinder is carefully executed by one diver (less disturbance by flippers, etc.). The fact that the cylinder is open-ended precludes the formation of a shock-wave (see MeNzIEs \& Rowe 1968). However, the vibrations resulting from the semi-rotatory movement of the cylinder may resuspend the upper sediment layers with a consequent dislocation of both epifauna and infauna (see BARNETT in discussion:

* 'Air-lift' samplers have also been used for marine biological work by Foss (1968), the Finnish IBP-PM group (1969), Delta Croce \& Chiarabini (1971), etc. 
Masse 1967). To guard against the possible escape of these organisms, it may be necessary to evacuate 'phasically' the cylinder contents.

Suction is initiated by gradually releasing compressed air into vertical pipe until a desirable intensity obtains. When working on coarse ground, the pipe opening should only be intermittently applied to the substrate. Otherwise the lumen becomes clogged with excayated material and the suction intensity will fall away to zero. Clearance is

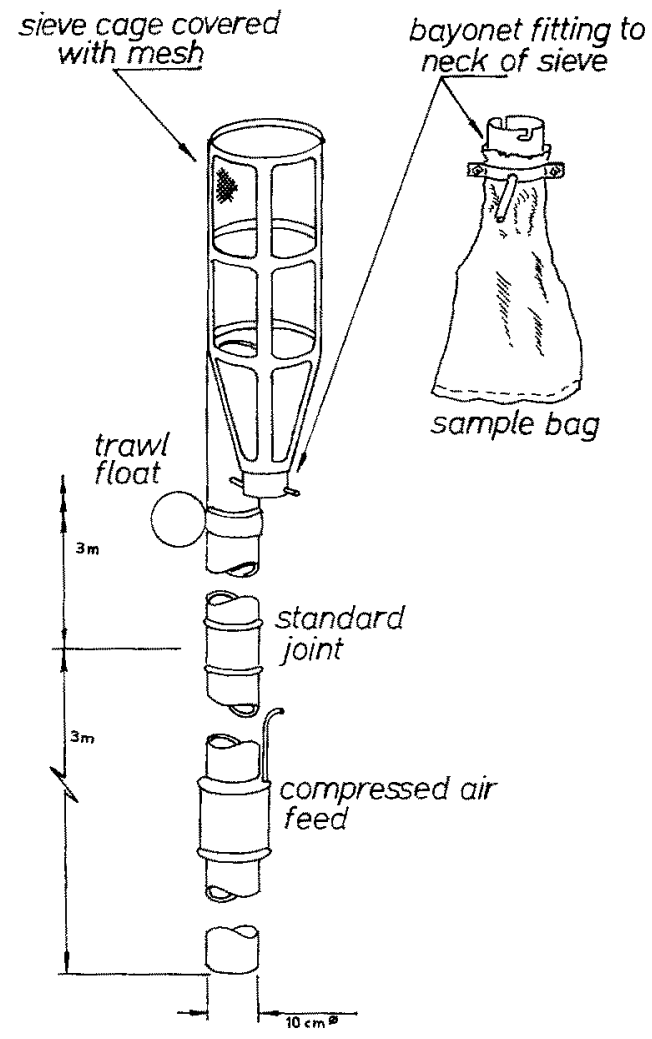

Fig. 1: "Air-lift" suction sampler and collecting bag (see BARNETT \& HARDY 1967)

quickly achieved by drawing 'unladen' water into the pipe. A jerky upward movement of the sampler can result in material being lost from the suction stream. Once sampling has been completed the air-flow should be continued until the pipe is clear.

Depending on the weight of the sample, it may be necessary to lay the pipe on the sea-bed before renewing the collection bag. Working on coarse ground, where most of the evacuated material is retained in the bag, the resultant weight increase may upset the vertical trim of the pipe. This is overcome either by piecemeal removal of the sediment, involving a number of bags, or, by the ploy of having a diver, equipped with a compensating buoyancy device, support the filling sample bag.

Throughout the operation, especially as one penetrates deep within the cylinder, it is desirable that the suction pipe be as near vertical as possible. In flowing water this 
may also require the presence of a diver at the upper end of the pipe. (In the frequently turbid conditions which can obtain in the vicinity of the "sieve cage", the diver may experience difficulties in orientation. A simple clinometer proved most helpful in such circumstances.) Layered sampling, useful in studying vertical distribution patterns, is readily achieved by tying off, "sausage-fashion", an elongate sample bag, thus separating the different fractions.

Operating at depths of between 6 and 25 metres, the time taken to evacuate the sampling cylinder rarely exceeded seven minutes. The air supply usually consisted of a standard single diving bottle. This normally permitted the taking of from 4-5 samples.

Advantages of the system are: (a) The system is reliable, deep-digging and has a high efficiency of capture. (b) It is easily operated from a small boat. (c) It is inexpensive, readily assembled and has few corrodable parts. (d) The sampling (suction) intensity can be regulated, thus making it possible to guard against fragmentation of the more fragile animals. (e) Once in operation, the system is wholly independent of the surface support vessel. (f) The immediate sampling area is maintained free of resuspended material.

Dis a d vantages of the system are, on the other hand: (a) Use of the system is restricted to within the diver's working limits of time and depth. (At depths of less than 6 metres the 'sucking action' is not very efficient.) (b) In fast flowing currents the elongate suction pipe can be highly unmanageable.

\section{Coresampler}

To further add to the findings on the vertical distribution of infaunal animals (as revealed by stratified suction sampling) an instrument was devised which permitted the collection of 'intact' columns of the deposit. These columns $-60 \mathrm{~cm}$ in length and $15 \mathrm{~cm}$ in diameter - are cored from the substrate, using a further application of the air-lift principle. Whilst the application may be original, it was suggested by the work of MACKERETH (1958).

Basically, the sampler (Fig. 2) consists of a cylinder which is forced into the sea bottom under hydrostatic pressure (see BARNETT \& HARDY 1967). This cylinder concentrically encloses - and rigidly confines - a 'core-tube' of smaller dimensions. Limited in use to sand/mud substrates, the sampler was designed so as to ensure minimum disturbance of the sediment core. The constructional details may be inferred from Figure 3.

The sampler is carefully positioned so as to cause minimum disturbance to the surface deposit. Before introducing compressed air into the evacuation tube, the operator must ensure that a good seal obtains around the base perimeter of the cylinder. To achieve this seal, it may be necessary to semi-rotate the cylinder some $f e w \mathrm{~cm}$ into the substrate. Once the air-flow has commenced the sampler should be 'pressured home' with the minimum of guidance/assistance from the operator. The time taken to penetrate to a depth of $60 \mathrm{~cm}$ varies (3-5 minutes) with the nature of the deposit. After the desired depth of penetration has been attained, the air-flow is shut off and the cylinder uncovered. This last operation requires that the actual lid be separated 
from the core tube proper. Having first closed the release valve, withdrawal can usually be accomplished with little frictional or adhesive resistance. (The sediment, at depths of 50-60 cm, was in general sufficiently cohesive to form a 'plug' in the lower core tube.) Once clear of the deposit, the core tube is sealed at its base and rapidly taken to the surface for immediate examination.

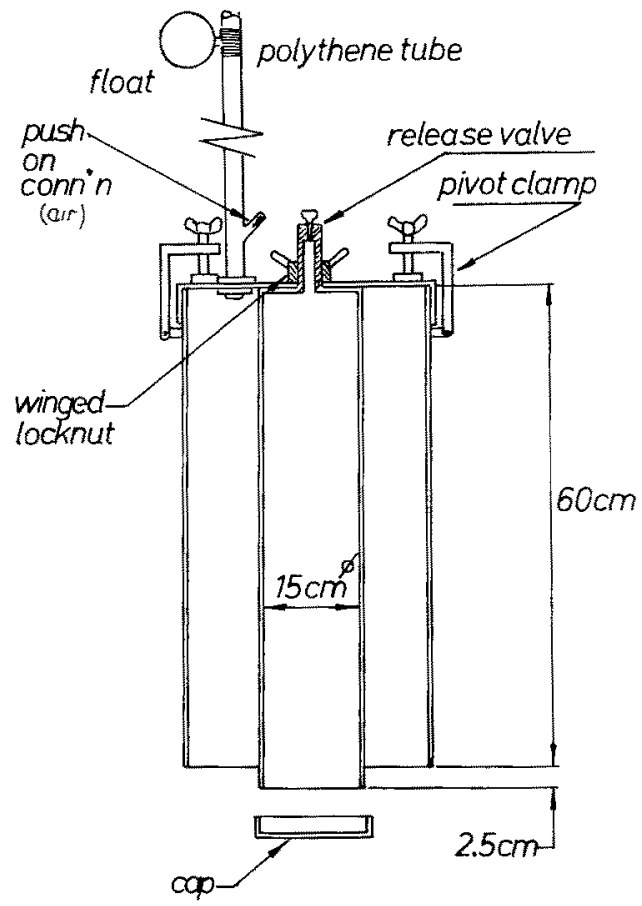

Fig. 2: Core-sampler. Sectional view

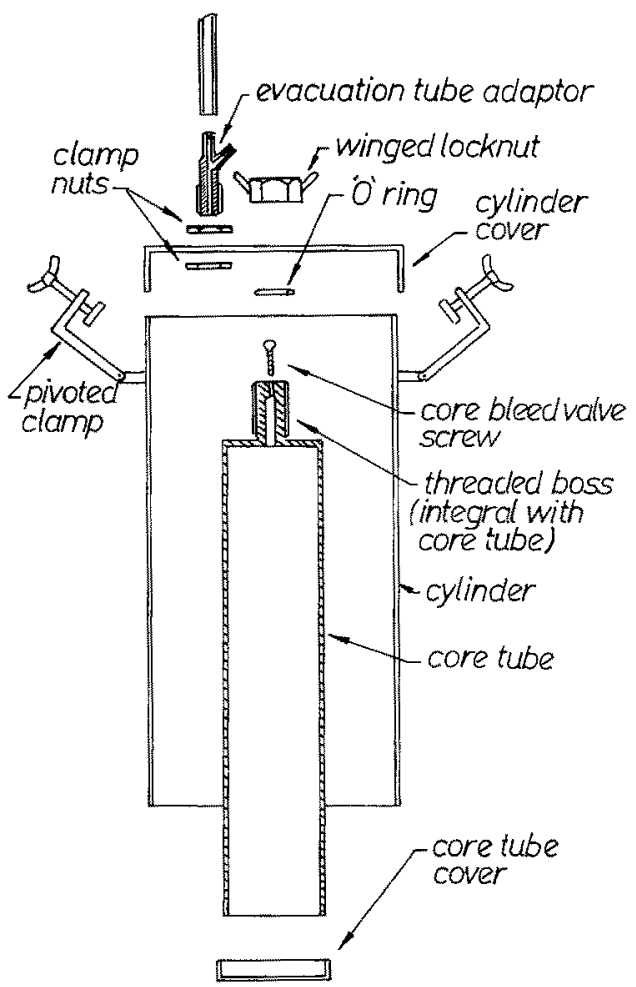

Fig. 3: Core-sampler. Exploded view

Advantages of the system are: (a) The cores are sufficiently large to be useful in quantitative macrobenthic studies. (b) Sampling is achieved with minimum disturbance to the retained sediment. (c) The sampler's size and simplicity ensures easy manipulation.

$D$ is a d va $n t$ age s are: (a) Use of the system is restricted to within the diver's working limits of time and depth. (b) It is unsuitable for coarse and uncompacted deposits.

\section{DISCUSSION}

Diver-operated suction samplers are conveniently categorised according to their manner of operation. Basically, there are two types: (1) Those which use the 'aspirator' principle to provide the suction effect; and (2) those which use the 'air-lift' principle to produce suction. 
The 'aspirator' type would appear to be the more popular and has been successfully employed by Brett (1964), Plante (1967) Emig \& Lienhart (1967), Masse $(1967,1970)$, etc.

The writers deemed it unsuitable for the following reasons: (a) the tendency for the whole field of operation to be 'blacked-out' by the sampler's sieving action (this is, naturally, most restricting in still water); (b) the likelihood that the 'sieving-surface' will clog when working on certain sediment types; and (c) the need for a permanent connection with the support vessel (cumbersome battery/pump units built into the sampler proper are equally restricting). Irrespective of their nature, the use of diver-controlled suction samplers should help to terminate speedily the unfortunate practice of referring animal densities to a unit area of sea-bottom. This convention is incomplete and lacks precision if the reported values are unaccompanied by information on, at minimum, the sampler's mean penetration into the substrate. Lacking such information, the data can be misleadingly interpreted as representing the totality of animals living on and below the specified unit area.

\section{SUMMARY}

1. The burrowing range of some infaunal animals and their accessibility to benthic sampling instruments is briefly considered.

2. An excavation depth of $>50 \mathrm{~cm}$ is deemed necessary for effective sampling of most deposits.

3. A diver-operated suction-sampler is described and evaluated. This 'air-lift' was used most successfully over a wide range of substrates.

4. Constructional and operational details are given for a new 'minimum-disturbance' core sampler.

Adknowledgements. We thank our Director, Professor P. O'CErDrgh and all the members of the Zoology Department who contributed to the success of the project. Our thanks, also, to the Irish Institute for Industrial Research and Standards which built the suctionsampler.

\section{LITERATURE CITED}

BARnetT, P. R. \& HARdy, B. L., 1967. A diver-operated quantitative bottom sampler for sand macrofauna. Helgoländer wiss. Meeresunters. 15, 390-398.

BrEtT, C. E., 1964. A portable hydraulic diver-operated sieve for sampling subtidal macrofauna. J. mar. Res. 22, 205-209.

Della Croce, N. \& Chtarabini, A., 1971. A suction pipe for sampling mid-water and bottom organisms in the sea. Deep Sea Res. 18, 851-854.

Emig, C. C. \& Lienhart, R., 1967. Un nouveau moyen de recolte pour les substrats meubles infralittoreaux: l'Aspirateur sous-marin. Recl Trav. Stn mar. Endoume 42 (58), 115-120.

Finnisf IBP-PM Group, 1969. Quantitative sampling equipment for the littoral benthos. Int. Revue ges. Hydrobiol. 54, 185-193.

Foss, G., 1968. Behaviour of Myxine glutinosa L. in natural habitat. Investigation of a mud biotope by succion technique. Sarsia 31, 1-14. 
Holme, N. A., 1964. Methods of sampling the benthos. Adv. mar. Biol., 2, 171-260.

HopkINs, T. L., 1964. A survey of marine bottom samplers. Prog. Oceanogr. 2, 213-256.

Knudsen, M., 1927. A bottom sampler for hard bottom. Meddr Kommn Danm. Fisk.-og Havunders. (Fiskeri) 8 (3), 3-4.

MACKeRETH, F. J. H., 1958. A portable core-sampler for lake deposits. Limnol. Oceanogr. 3 , $181-191$.

MASSE, H., 1967. Emploi d'une succeuse hydraulique modifiee pour les prelevements quantitatifs dans les substrats meubles infralittoraux. Helgoländer wiss. Meeresunters. 15, 500-505.

- 1970. La suceuse hydraulique, bilan de quatre annees d'emploi, sa manipulation, ses avantages et inconvenients peuplements benthiques. Tethys 2, 547-556.

Menzies, R. J. \& RowE, G. T., 1968. The LUBS - a large undisturbed bottom sampler. Limnol. Oceanogr. 13, 708-714.

Plante, R., 1967. Etude quantitative du benthos dans la region de Nosy-Bé: Note preliminaire. Cah. O.R.S.T.O.M. (Oceanogr.) 5, 95-108.

RenNeCK, H. E., 1958. Kastengreifer und Lotröhre „Schnepfe“, Geräte zur Entnahme ungestörter, orientierter Meeresgrundproben. Senckenberg. leth. 39, 42-48.

First author's address: B. F. KEEGAN

\author{
Zoology Department \\ University College \\ Galway \\ Ireland
}

